\title{
Students’ Self-Concept, Knowledge of Verbal Reasoning Skill and Learning Readiness as Correlate of Achievement in Civic in Senior Secondary Schools in Osun State, Nigeria
}

\author{
Babatunde Adeniyi Adeyemi \\ Obafemi Awolowo University, Ile Ife, Osun State, Nigeria
}

\begin{abstract}
The study examined the relationship of students' self-concept, knowledge of verbal reasoning skill and learning readiness as correlate of achievement in Civic in senior secondary schools in Osun State, Nigeria. The study employed correlational survey research design. The population consisted of senior secondary schools 2 Civic students in public secondary schools in Osun State Nigeria. Simple random sampling technique was employed in selecting 10 local governments from the 30 local governments in Osun State. Ten schools were selected using simple random sampling from each of the selected ten local governments, 60 SS2 students were then selected from each of the ten schools using simple random sampling technique. Four research instruments were developed, validated and used for the study. The data collected were analyzed using Pearson Product Moment Correlation Coefficient and Regression Analysis. The study concluded among others, that students' self-concept, knowledge of verbal reasoning skill and learning readiness had composite effects on students’ achievement in Civic.
\end{abstract}

Keywords: self-concept, verbal reasoning, students’ readiness and achievement in Civic

\section{Introduction}

Civic education is concerned with the development of values, social norms, skills and democratic ideals in the citizens. Civic as a discipline deals with the world and the people. It covers a wide range of issues, topics and legislation that impact on people's lives and daily living at all time. It teaches young people on how to get the best out of their world. According to Ozumba and Eteng (1999), the basic objectives of civic education include:

(1) Enhancement of political literacy among the Nigerian people;

(2) Creation of a deep sense of awareness of the fundamental right of citizens;

(3) Exposure of students to the knowledge of the Nigerian constitution and provisions as well as its operation;

(4) Provision of essential knowledge on democracy;

(5) Sensitization of the people to the role of government as well as citizens' obligations and duties;

(6) Enhancement of human development and promotion of reasonable self assurance among the citizens through the teaching of good values and morals in order to become responsible people of the state; and

(7) Serves as a reversal of the colonial situation where Nigerians were compelled to accept European values, preferences and world views (pp. 4-5).

Babatunde Adeniyi Adeyemi, Ph.D., Institute of Education, Faculty of Education, Obafemi Awolowo University. 
It should be noted that the general objectives of Education in Nigeria could not be divorced from the objectives of Civic Education. According to National Policy on Education NERDC (2013), the following are the aims and objectives of Education in Nigeria:

(1) Inculcation of national consciousness and national unity;

(2) The inculcation of the right type of values and attitudes for the survival of the individual and the Nigerian society;

(3) The training of the mind in the understanding of the world around; and

(4) The acquisition of appropriate skills objectives and competences both mental, physical, as equipment for the individual to live in and contribute to the development of his society.

From the above, the objectives of Civic Education and that of National Policy on Education go pari-pasu. It is hoped that through the teaching of Civic Education, students would attain some of the conceptual, process skills and effective outcomes of instruction. No wonder Falade and Adeyemi (2015) asserted that if the teaching of Civic Education is given the right status in the Nigerian school programme, Nigeria will experience enduring peace and national integration after one hundred years of existence.

Lot of studies had been conducted in the area of students' achievement. It is generally assumed that the students who showed better or higher performance in the starting classes of their studies also performed better in future academic years at degree level. Reddy and Talcott (2006) in their research on the relationship between previous academic performance and subsequente achievement at university level found that students learning or studying at graduate level and the score secured did not predict any academic achievement at university level. It is on this note, that the study equally examined senior secondary students' achievement in Civic as a discipline in relations to variables such as students' self-concept, knowledge of verbal reasoning skill and students' readiness to learn.

Self-concept according to Bandura (1997) is defined as individuals' beliefs about themselves in term of their academic, social, athletic and personal capabilities and characteristics. According to Schunk, Pintrich, and Mecce (2008), positive self-concept leads students to academic goal attainment, makes them feel less anxious in achievement settings, enjoy their academic work more, persist longer on difficult tasks and overall, feel better about themselves as persons and as students. In other words, they are likely to attend to instruction, participate in tasks, and rehearse information to be remembered, expand efforts, persist on challenging tasks and have proximal specific and moderately difficult goals. They also feel competent in skills and have high confidence in their ability to learn and perform on their tasks. In relation to Civic as a discipline, studies self-concept about Civic as a discipline as well will assist them to have good understanding pertaining to the subject which will in turn affect their mental abilities, special abilities and interest.

Verbal reasoning has to do with skills of reading and reading. It is generally taught through oral or written instruction. It involves making meaning based on the information given, going beyond that information to better understanding and applying verbal skills to new learning. While speaking and listening are parts of verbal reasoning most formal verbal reasoning involves reading and writing. Ability to master verbal reasoning skill will assist students to tackle bit by bit some of the basic problems associated with reading, writing and spelling.

Learning readiness refers to how likely a person is to seek out knowledge and participate in behaviour change. There must be readiness on the part of students for effective learning to take place. Factors such as physical or psychological comfort such as pain, fatigue, anxiety or fear can affect a person's ability and motivation to learn. 


\section{Statement of the Problem}

Students' achievement has been seen to be dependent on so many factors, which researchers from various fields gave different names among which are correlate. Civic is a newly introduced subject in the school curriculum of Nigerian educational system. It is taught from basic lower primary schools to senior secondary schools. As a result of its newness, only few sets of students have graduated at the SSCE level. The level of achievement in the subject cannot yet be evaluated, however some variables that are vey germane to its attainment such as students' self-concept, students knowledge of verbal reasoning as well as students' readiness could be assessed; hence the study.

\section{Hypotheses for the Study}

(1) There is no significant relationship between students' self-concept and their achievement in Civic;

(2) There is no significant relationship between students' knowledge of verbal reasoning skill and their achievement in Civic;

(3) There is no correlation between students' readiness and their achievement in Civic;

(4) There will be no significant composite effect of students' self-concept, knowledge of verbal reasoning said and readiness on their achievement in Civic.

\section{Methodology}

The study was a correlational survey research design. The population constituted of senior secondary schools 2 Civic students in public secondary schools in Osun State, Nigeria. Simple random sampling technique was employed in selecting 10 local governments from 30 local governments in Osun State, 10 schools were selected using simple random sampling from each of the selected ten local governments, 60 SS2 students were selected also from each of the schools selected using simple random sampling techniques: Four research instruments namely, Students' Self-Concept Scale (SSCS), Knowledge of Verbal Reasoning Test (KVRT), Students' Readiness Scale (SRS) and Civic Achievement Test (CAT) were developed, validated and used for the study.

SSCS is a scale consisted of 20 items that measured students' self-concept of Civic. The items are of likert type formed with response ranging from very true of me to never true of me. A reliability coefficient of 0.80 was obtained using cronbach alpha.

KVRT scale was constructed by the researcher and latter validated with the use of split-half method and later Spearman Brown formula was used and reliability of 0.85 was obtained.

SRS scale contained 20 items that measured students' readiness for Civic. The items are of likert type formed with responses ranging from very true of me to never true of me. A reliability of 0.84 was obtained using cronbach alpha.

CAT consisted of 60 items objectives test bases on scheme of work that had been covered by the students. The instrument was validated with the use of split-half method and latter Spearman Brown formula was used and a reliability of 0.73 was obtained.

The researcher visited the schools personally and contacted the principal and teachers for assistance and cooperation. Data collected were analyzed using Pearson Product Moment Correlation coefficient and Regression Analysis. 


\section{Results}

\section{Hypothesis 1: There Is no Significant Relationship Between Students' Self-Concept of Civic and Their} Achievement.

Table 1

Correlation of Civic Self-Concept and Achievement

\begin{tabular}{lc}
\hline Parameter & Value \\
\hline Pearson Product moment correlation coefficient n $(r)$ & $0.976^{*}$ \\
Number & 600 \\
$P$-value & 0.000 \\
\hline
\end{tabular}

Note. ${ }^{*}$ Significant at $p<0.05$.

Table 1 showed that the Pearson correlation coefficient " $r$ " obtained was 0.976 , while the probability level was equally 0.000 which is less than 0.05 alpha levels. Therefore, the null hypothesis is hereby rejected; hence, there is significant relationship between students' self-concept of Civic and their achievement in Civic.

\section{Hypothesis 2: There Is no Significant Relationship Between Students' Knowledge of Verbal Reasoning Skill and Their Achievement in Civic.}

Table 2

Correlation of Knowledge of Verbal Reasoning and Achievement

\begin{tabular}{lc}
\hline Parameter & Value \\
\hline Pearson Product moment correlation coefficient $\mathrm{n}(r)$ & $0.462^{*}$ \\
Number & 600 \\
$P$-value & 0.000 \\
\hline
\end{tabular}

Note. ${ }^{*}$ Significant at $p<0.05$.

Table 2 showed that the Pearson correlation coefficient " $r$ " obtained was 0.462 , while the probability level was equally 0.000 which is less than 0.05 alpha levels. Therefore, the null hypothesis is hereby rejected; hence, there is significant relationship between students' knowledge of verbal reasoning skill and their achievement in Civic.

\section{Hypothesis 3: There Is no Correlation Between Students’ Readiness and Their Achievement in Civic.}

Table 3

Correlation of Civic Learning Readiness and Achievement in Civic

\begin{tabular}{lc}
\hline Parameter & Value \\
\hline Pearson Product moment correlation coefficient n $(r)$ & $0.523^{*}$ \\
Number & 600 \\
$P$-value & 0.000 \\
\hline
\end{tabular}

Note. *Significant at $p<0.05$.

The Table 3 showed that the Pearson correlation coefficient " $r$ " obtained was 0.523 , while the probability level was equally 0.000 which less than 0.05 alpha levels. Therefore, the null hypothesis is hereby rejected; hence, there is significant relationship between students' readiness and their achievement in Civic. 


\section{Hypothesis 4: There will be no Significant Composite Effect of Students' Self-Concept, Knowledge of Verbal Reasoning Skill and Readiness on Their Achievement in Civic.}

Table 4

Multiple Regression of Students' Self-Concept, Knowledge of Verbal Reasoning Skill and Learning Readiness on Civic Achievement

\begin{tabular}{ll}
\hline Parameter & Value \\
\hline Multiple Regression $(R)$ & $0.977^{*}$ \\
$R$-Square & 0.954 \\
Adjusted $R$-Square & 0.954 \\
Regression $F$-ratio & 4100 \\
$D f$ & 3,596 \\
$P$-value & 0.000 \\
\hline
\end{tabular}

Note. *Significant at $p<0.05$.

Table 4 revealed that the overall model of three independent variables (Civic self-concept, knowledge of verbal reasoning skill and learning readiness) significantly predict Civic achievement $R^{2}=0.977, R^{2}$ adj. $=$ 0.954, $F(3,596), p<0.05$. This model accounted for $95.4 \%$ of variance in Civic achievement. Further verification using multiple regression ANOVA however produced $F$-ratio $=4100, p<0.05$. Therefore, the null hypothesis is hereby rejected. Hence, there will be significant composite effect of Civic self-concept, knowledge of verbal reasoning skill and readiness on students' achievement in Civic.

\section{Discussion}

The results of Hypothesis 1 in Table 1 showed that there was positive relationship between students' self-concept of Civic and their achievement $(r=0.976, p<0.05)$. The response of the students to the items in SSCS, showed that the conception of students about Civic determined their performance in Civic. It was observed that those that have positive conception about Civic actually perform better. Those who have negative feeling towards Civic perform below expectation in the achievement test given to them. This is a strong indication that whatever the conception of students about Civic determined their overall performance. If students have negative conception of Civic as subject very difficult, it will in turn affects their performance negatively. Also, if the conception is positive the performance will also be affected positively. This result tallied with findings of Ghazuini (2011) who was of the view that academic self-concept powerfully and positively predicts general performance in Literature and Mathematics. Other similar studies that affirmed positive influence on academic performance were Acosta (2001), Adeyemi (2009), Flowers, Raynor, and White (2013), Dramanu and Balarabe (2013), and Adeyemi (2014).

The result of Hypothesis 2, presented in Table 2, with $r=0.462, p<0.05$ indicated that there was a significant relationship between students' knowledge of verbal reasoning and their Civic achievement. The results pointed out that students' performance in Civic would be totally affected if students do not have adequate knowledge of verbal reasoning skills. The results of this finding revealed that reasoning skills hold a very better place in the performance of students in Civic. Similar findings such as Terrel and Johnson (1989), Cavallo (1996), Yenilmez, Sungur, and Tekkaya (2006), Yilmaz and Alp (2006), Yong (2007) as well as James (2011) gave credence to the evidence that there was positive relationship between verbal reasoning and students' academic performance. 
Furthermore, the results presented in Table 3 showed that $r=0.523, p<0.05$. This implied that a significant relationship existed between students' readiness and achievement in Civic. The above findings supported that of earlier findings such as Vashe, Devi, Rao, and Abraham (2013), Perras (2014), and Kirmizi (2015) who were equally of the views that there was a significant relationship between students' readiness and their academic achievement.

Finally, the results of Hypothesis 4 presented in Table 4, with $R$ calculated $0.977^{*}$ and $F=4100$ indicated that students' self-concept, knowledge of verbal reasoning and learning readiness still have composite effect on students' performance in Civic. This implies that the three identified independent variables affected the level of performance in Civic. In a related matter, Boujaoude, Salloum, and Khalick (2004) in their findings established that relationship existed between selected cognitive variables and students' ability to solve Chemistry problems.

\section{Conclusion}

Based on the findings, it could be concluded that many students that have positive self-concept about Civic performed better in Civic than those that have negative self-concept of the subject. Also, some students do not possessed adequate knowledge of verbal reasoning skills needed for the attainment in Civic and thus had effect on their performance in the subject. Students that showed high level of readiness level for Civic performed creditably well in Civic than those that showed low readiness level. Above all self-concept, knowledge of verbal reasoning skill and learning readiness had composite effects on students' achievement in Civic.

\section{Recommendation}

Based on the findings of this study, the following recommendations are put forward in the school by the teachers. Efforts should be made by subject teacher in ensuring that students develop positive self-concept on the subject. Parents should not be left out in the education of their wards. Parents should give day to day counseling services to their wards at home before entering school. Also, day to day educative tasks should be given to the students in the schools to enable them develop positive self-concept of the subject. Teachers are equally expected to be role model to their students in such a way that what the teachers are teaching, they are practicing.

\section{References}

Adeyemi, B. A. (2009). Students' self concept, attitude and achievement in social studies in junior secondary schools in southern Nigeria. Paper presented as International Conference of Education, Research and Innovation, Nov 16-18, Madrid, Spain 004087-004094.

Adeyemi, B. A. (2014). Self concept and motivation variables as correlates acquisition of ICT competence among social studies students of Obafemi Awolowo University, Ile Ife, Nigeria. World Journal of Education, 4(2), 76-87.

Acosta, E. S. (2001). The relationship between school climate, academic self concept and academic achievement. Dissertation Abstract International section A: Humanities and Social Sciences, 62(5-A), 1717.

Bandura, A. (1997). Self efficacy: The exercise of control. New York: Freeman.

Boujaoude, S. B., Salloum, S., \& Khalick, F. (2004). Relationship between selected cognitive variables and students' ability to solve chemistry problems. International Journal of Science Education, 26, 63-84.

Cavallo, A. M. L. (1996). Meaningful earning, reasoning ability and students' understanding and problems solving of topics in genetics. Journal of Research in Science Teaching, 33, 625-656.

Dramanu, B. Y., \& Balarade, M. (2013). Relationship between academic self concept and academic performance of junior high school students in Ghana. European Scientific Journal, 9(34), 1-12. 
Falade, D. A., \& Adeyemi, B. A. (2015). Civic education in Nigeria's one hundred years of existence problems and prospects. Journal of Emerging Trends in Educational Research and Policy Study (JETERPS), 6(1), 113-118.

Federal Ministry of Education. (2013). National policy on education. Lagos: NERDC Press.

Flowers, L. O., Raynor, J. E., \& White, E. W. (2013). Investigation of academic self concept of undergraduate in STEM courses. Journal of Studies in Social Sciences, 5(1), 1-11.

Ghazuini, S. D. (2011). Relationships between academic self-concept and academic performance in high school students. Procedia-Social and Behavioural Science, 15, 1034-1039. The 3rd World Conference on Educational Sciences.

James, D. (2011). Verbal Aptitude Test: Practice aptitude tests. Retrieved 31 July 2011.

Kirmizi, O. (2015). The influence of learner readiness on student satisfaction and academic achievement in an online programme at higher education. The Turkish online Journal of Educational Technology, 14(1), 1-10.

Ozumba, G. O., \& Eteng, F. O. (1999). Concept of citizenship education. In G. O. Ozumba, F. O. Eteng, \& M. Okam, Citzenship education. Aba. Casell Prints.

Perras, D. (2014). Student readiness to achieve: Decreasing the achievement gap. Retrieved from http://www.seen magazine.us/article detail/art

Reddy, P., \& Talcott, J. (2006). Predicting university success in psychology: Are subject-specific skills important? Retrieved July 4, 2008, from http//www.aston as.uk/downlands/ms/peelea/huw2006p.pdf

Schunk, D. H., Pintrich, P. R., \& Meece, J. L. (2008). Motivation in education: Theory, research and applications (3rd ed.). Upper Saddle River New Jersey: Pearson/Merill Prentice Hall.

Terrel, D. J., \& Johnson, J. M. (1989). Logic, reasoning and verbal behaviour. The Behaviour Analyst, 12(1), 35-44.

Vashe, A., Devi, V., Rao, R., \& Abraham, R. R. (2013). Link between self-directed learning readiness and academic performance of medical students: MOC innovation and Technology in Education. Paper presented at IEEE International Conference, Jaiper, Dec. 20-22, 2013, PJS 130-133.

Yenilmez, A., Sungur, S., \& Tekkaya, C. (2006). Students' achievement in relation to reasoning ability, prior knowledge and gender. Research in Science \& Technology Education, 24(1), 129-138.

Yilmaz, A., \& Alp, E. (2006). Students' understanding of matter: The effect of reasoning ability and grade level. Chemistry Education Research and Practice, 7(1), 22-31.

Yong, B. C. S. (2007). Relationship between reasoning abilities and students' achievement in science a case study. Journal of Applied Research in Education, 11, 109-119. 